\title{
AUTHENTICITY: IT SHOULD AND CAN BE NURTURED
}

\author{
By \\ Susan T. Gardner and Daniel J. Anderson \\ sgardner@capilanou.ca, danieljohnanderson@hotmail.com
}

\begin{abstract}
(100 words)
Introduction

Philosophy: what is the point? This question is particularly pertinent to those of us who are engaged in the uphill battle of attempting to bring philosophy to all of the world's citizenschildren and adults alike. Most often, this question is answered by referring to the potential for increasing reasoning power and expanding cognitive perspectives. Enhancing the capacity for empathy is frequently mentioned as well. Here, we focus on a different potential, namely the potential for solidifying a worthy personal goal. More specifically, we argue that it is imperative that we, who are philosophical educators, have a vision of the goal: "In the service of what do we want to expand thinking power?"
\end{abstract}

Elsewhere, Gardner (2009), a co-author of this article, has argued that the only responsible way to sell the merits of improving thinking skills is to show how, as a result, individuals gain the capacity to become more autonomous, or "free," in the sense of becoming more self-legislating. However, this assertion, if taken superficially, can be misleading. On the one hand, "becoming more free" can be "over-Kantianized" in the sense of being interpreted as enhancing one's capacity for solitary rational thinking free from the input of others. On the other hand, "becoming more free" can be "under-Kantianized" in the sense of being interpreted as 
either mere license, or the capacity to manipulate others to one's will, i.e., unhinged, or free, from any standards of rationality altogether, i.e., free to do whatever one wants to do. ${ }^{1}$

In this paper, we attempt to stabilize the notion of autonomy by marrying Kant's notion of "solitary thinking" to a more Habermasian notion of "thinking through dialogue," and then weaving this dialogical perspective into an Existential structure, upheld, in part, by references to Charles Taylor, to psychiatrist R.D. Laing and to neuroscientist Daniel Siegel. As a result of these deliberations, we argue that we ought to overtly counsel our charges of the merits of authenticity, and, thereafter, to develop educational strategies so that we nudge one another toward that goal. Paradoxically, we claim that learning to become authentic-learning to become one's own person — can only be done through interpersonal dialogue, and that educational strategies that focus on enhancing the right kind of "authenticity-producing interchange," along with those that enhance reasoning skills, are the sort that we ought to be gifting to our children. In other words, that though authenticity must be grasped/created/embodied from the inside, authenticity can nonetheless be incubated in an environment in which its pursuit as a genuine possibility is made evident, in which its value is made paramount, and in which individuals become entangled in matrices of interpersonal reasoned interaction that are both engaged and objective.

\section{What are the Criteria for Authenticity?}

We suggest, at a minimum, the following five criteria for an "authenticized" notion of autonomy.

\section{1) An authentic person must recognize that persons are not objects.}

In ordinary everyday life, the notion of authenticity is most typically used in conjunction with objects, e.g., "this is an authentic diamond." When persons begin to think of authenticity in 
this vein, they may come to believe that just as an authentic diamond must be the same throughand through, so a sufficient condition for authenticity is being the same through-and-through; that they are authentic if their "outside" matches their "inside." For example, hitting Frankie, then, could be described as an authentic act because I really wanted to hit Frankie. In a similar vein, authenticity might be perceived as a function of some long-term characteristic, e.g., I am authentic when I am angry because I have always had a bad temper. So, whatever else an authentic person must recognize, s/he must recognize that the predicate "authentic" changes its meaning entirely when applied to persons rather than objects—-which brings us to the next 4 more positive points.

\section{2) An authentic person must see herself as a future-oriented self-propelling process.}

Persons, because they are self-conscious language-users and have the capacity to imagine themselves in the future and hence can direct their present behaviour accordingly, are best described as "future-oriented processes." The descriptive "authenticity," then, must capture the fact that no static description can accurately characterize who I am, let alone justify any of my actions. Authentic persons, thus, can only accurately describe themselves in the present by reference to who it is that they are choosing to become. An authentic self-description is thus, in a sense, a promissory note that stands in relation to a person's ideals or values. Hence, the only means of evaluating the authenticity of persons is to ask them questions that will elucidate whether there is a discrepancy between their ideal and their current actions, i.e., whether their present actions align with the life project they are proposing. In "existential analytic" terms, this would be referred to as "inner consent" (Klaassen 2014), i.e., that one quite literally asks oneself whether one consents to do what one is doing or about to do. 


\section{3) An authentic person must recognize that $\mathrm{s} / \mathrm{he}$ is always responsible for what $\mathrm{s} / \mathrm{he}$}

does-a responsibility that becomes evident by a reasoned reference to a temporal dimension.

Let's look at the following examples: "I did $\mathrm{x}$ because he made me do it. I did $\mathrm{x}$ because everyone else is doing x. I did x because I had no choice." Note that the reasoning offered in these examples deflects responsibility away from the self; it is the kind of reasoning that suggests a sort of bystander attitude towards one's own life. By contrast, the reasoning required to signal genuine responsibility must show that, though the actor may have had little control over the circumstance in which s/he found herself, s/he nonetheless had a choice as to how to respond, and her justification for how she responded must show how s/he believes the course of action chosen contributes to the person s/he hopes to become. Authenticity, in other words, requires that we hold one another personally accountable in the sense of seeking justification relative to a future vision, albeit also relative to circumstance and personal context. Who is it that you are consenting to become by doing what you did?

\section{4) An authentic person must recognize that s/he can self-create only relative to given circumstances and personal context.}

Self-creation is always relative to the circumstance and personal context; a point emphatically stressed by Viktor Frankl in his book, Man's Search for Meaning (1984). Though this point may seem obvious, failure to recognize "freedom's context" can, quite literally, be counterproductive. This is so because, for instance, if students are enthusiastically encouraged to self-create $a$ priori $^{2}$ and then, subsequently, they find their plans and expectations thwarted (perhaps utterly), such a failure in expectations and aspirations can decimate the plausibility of self-creation, and reinforce the notion that they are merely victims of circumstance-i.e., objects damaged by life. 


\section{5) An authentic person must recognize that s/he can self-create only in relation to objective descriptives that must be justified in interpersonal space.}

The possibility of authentic self-creation is also endangered if the limited degree of control that anyone has over the description of what they do, and consequently, who they are, is also not emphasized. Such, indeed, is the danger of self-help books that market the solipsistic, arrogant notion of the power of positive thinking: "As long as I believe that I am worthy of esteem, I will have self-esteem." Authorship over self-descriptives (or evaluative predicates) is not and cannot be a private affair, any more than a private language is possible, as Wittgenstein (1968) was at such pains to point out some time ago. Evaluative predicates don't stick just because someone says so. Evaluative predicates stick with the glue of reason. Evaluative predicates stick because they are backed by the "least weak" (Gardner, 2009) of the reasoned arguments that support competing alternatives. This leads us to the following conclusion: Who you are, and the degree to which you have power over who it is that you are becoming, is not only a function of what you do, but, as well, your ability to reason through to the best description of what you do-hopefully, before you do it. And reasoning, as argued below, is, at its core, an "inter-" rather than an "intra-"subjective process.

\section{Authenticity-Enhancing Education}

With a description of authenticity in hand - that authenticity requires that we view ourselves as forward-oriented processes actively responsible for responding to ever-changing circumstances which, in turn, will attract descriptives that, if objective, will call for ownershipwe are now in a position to outline the sort of educational strategies that might enhance its possibility. Given the above, we articulate three principles. First and foremost, the whole notion of authenticity, and its worth, must be explicated explicitly, i.e., in order to move toward the goal, we need to know what the goal looks like. Second, we argue that becoming alert to the power of 
one's own self-creation can only happen within interpersonal space, and that we need to create dialogical opportunities in which participants become more skilled in the kind of "interpersonal language of freedom" that is necessary to nurture authenticity, including communicative interchanges that are (i) contingent, (ii) threaded with "liberation-enhancing questions," and (iii) "process" rather than "object" oriented. Third, we argue that we need to insist on developing the sort of reasoning skills that are necessary to recognize when reason's 'glue' is or will be (or is not or will not be) strong enough to keep evaluative predicates in place. We will address these points in turn.

\section{1) Explicating the goal.}

In his book The Ethics of Authenticity (2003), originally part of the CBC's 1991 Massey lecture series entitled The Malaise of Modernity, Charles Taylor argued that the modern emphasis on self-fulfillment that appears to underwrite the current trend toward relativism, nihilism, and the lack of civic participation, does not deserve the cynical interpretation of a mere back-sliding into biologically-based selfish egoism, as suggested, for instance, in Allan Bloom's The Closing of the American Mind (1987). He argued, rather (and perhaps surprisingly), that this apparent epidemic of narcissism is actually a misplaced reaching for an extremely high ideal, namely "authenticity." Like over-confident trapeze artists, we are reaching for the highest bar, but due to the drag of serious conceptual confusion, we are falling short, and, in so doing, potentially tumbling toward our demise. In other words, it is precisely because we are trying to be authentic, but are confused with regard to what authenticity looks like, that we are moving away from, rather than toward, the goal.

In supporting this claim, Taylor (2003) explored the emergent roots of the call to authenticity through Rousseau, Locke, Nietzsche, and others, and argued that, unlike earlier societies in which a person's identity was largely fixed by his or her social position, we are 
required, whether we like it or not, to negotiate our identities with others; a negotiation that, importantly, can succeed or fail. He vehemently criticizes those who deem themselves authentic solely as a function of "self-choice"; it is simply unintelligible, he argues, for me to believe that I could just decide that what is significant or admirable about my life is wiggling my toes in warm mud (p 36). We all, according to Taylor, must make claims with regard to our identity — what we are referring to here as "evaluative predicates" - against what he refers to as "horizons of significance" (p. 37).

What Taylor is arguing is that both the "knockers" of society who despair of the new unfettered selfishness, and the "boosters" who celebrate this narcissism as a new form of selffulfillment (p. 72) are blind to the pervasive never-ending and absolutely necessary modern struggle of self-creation. According to Taylor, we ought not to be knocking one another for being so self-centered, nor ought we to simply relax in a celebration of the modern era's materialistic overabundance. What we are called to do, rather, in order to combat the Malaise of Modernity and all the psychological, sociological, and political problems that it brings, is first to see that the struggle for an authentic self-identity is the challenge of the age, and that we must all get involved in formulating a far more precise and hence demanding notion of what that ideal indeed requires of us (p. 72). Such a description is precisely what is being offered here.

However, once such a description is in hand, it behooves us to go further and articulate, at least in broad strokes, what sort of educational strategies ought to be employed so that authenticity's possibility can move toward actuality. Since self-creation, whether authentic or not, happens only through interpersonal dialogue (Mead,1965; Taylor, 2003), what is needed is a more precise analysis of what kind of interpersonal dialogue propels us toward, or away from, the goal we seek. We will refer to the kind of dialogue that enhances authenticity as the "language of freedom." 


\section{2) Creating Specific Dialogical Opportunities that Offer an Immersion in the "Language of Freedom"}

In making the argument that the self only emerges through dialogue, Mead, most famously known for his insistence that interpersonal dialogue is a necessary condition for the emergence of self-consciousness per se (1965), has become, to many who promote a dialogical form of education, a standard bearer. Thus, those of us in the Philosophy for Children movement have often assumed that the Community of Inquiry is a likely candidate for being heralded as a significant educational strategy for priming the pump of self-creation. However, as we argue here, such accolades need to be kept at bay until a more precise account of the kind of dialogue that is necessary for self-creation that is authentic is analyzed more fully. If it is the case that in order to reach toward authenticity, self-creating communicative interchange needs to be "contingent," threaded through with "liberating questions," and "process," rather than "object" oriented, then it would seem to follow that facilitators of Communities of Inquiry must be far more actively and genuinely "engaged" than has hitherto been recognized. If, as may be common, the facilitator tries, as it were, to disappear so as not to steal the participants' thunder, if s/he acts almost entirely like a gate keeper, if the facilitator depends too much on dynamics of the community itself to move towards truth (a strategy often promoted in calls for dialogic as opposed to monologic pedagogical approaches (Reznitskaya, 2012), too many contributions will pass into the mix unconfirmed, too many opportunities for agent-recognition will be missed, and too much object-referencing will go uncorrected. We describe each of the subcategories on the language of freedom mentioned above in turn.

\section{(i) "Contingent" communication.}

R.D. Laing (1969) argued that how we communicate with one another can either have a confirming or disconfirming impact on one another's identity, i.e., it can help or stultify the 
process of self-creation. To illustrate his point, he used the example of a 5-year old boy running to his mother saying "Mummy, look what a big worm I have got" (p. 102). The mother responds in a disconfirming or stultifying way in saying, "You are filthy_away and clean yourself immediately."

What is important to note about this example is that Laing is not faulting the mother for not showing delight in being presented with a worm. Laing, rather, is faulting the mother for not seeing the boy by acknowledging the boy's agency. Specifically, Laing says of the mother that she fails "to endorse what the boy is doing from his point of view, namely showing his mummy a worm" (p. 103). Instead of using such "tangential” responses, Laing argues that we ought instead to use confirmatory responses. He describes a confirmatory response as a direct response; it is "to the point," or "on the same wavelength as the initiatory or evocatory action" (p. 99). Laing stresses that a confirmatory response need not (importantly) be in agreement, or gratifying, or satisfying. Rejection can be confirmatory if it is direct, not tangential, and recognizes the evoking action and grants it significance and validity.

What Laing referred to as a "confirmatory response," Daniel Siegel, writing from the point of "Interpersonal Neurobiology (IPNB)," i.e., a field that studies how interpersonal interaction affects the structure of the brain, refers to as "contingent responses." In his book The Developing Mind (2012), Siegel argued that interpersonal communicative interaction—both early in life and throughout adulthood - play a central role in shaping the brain and, along with it, the ever-emerging mind. Siegel stressed that what is important in shaping our identities is not just that we are involved in relationships per se, nor that we engage in interpersonal communication per se. What is important is that we are involved in contingent communication (p. 34) by which he means that we respond to one another in a way that suggests that the other is seen as having an internal centre of subjective life worthy of attention (p. 105); that, in communicating with the 
other, we are attempting to see the other's minds - what Siegel refers to as "mind-sight" (p. 34).

An integrated sense of self, or what Laing (1972) would refer to as a self "undivided," requires, according to Siegel, integrative communication, i.e., communication that integrates us with one another, which, in turn, allows integrative neurophysiological changes to occur throughout life.

If the above carries insight, then it seems to follow that if a facilitator of a community of inquiry, or indeed anyone in any kind of interpersonal interchange, does not feel that s/he has either practical or theoretical permission to respond contingently to offerings by members of the community, tangential responses may well become the norm. Contributions by participants will just fall into the mix, and frequently, perhaps more often than not, be unrecognized. For reasons already mentioned, such "opinion tourism" will do more harm than good when it comes to its potential for enhancing authentic self-creation.

\section{(ii) "Liberating Questions."}

Gardner (1996) recommended to those who facilitate Communities of Inquiry to be alert to the possibility of asking a "second why," so that if, for example, the teacher asks Johnny why he hit Frankie, and Johnny responds that he hit Frankie because Frankie hit him, the teacher needs to ask again, but why did you think that hitting Frankie in response to him hitting you was a good idea? This is exactly the sort of language — this is exactly the sort of question — that gives birth to the kind of justificatory reflection that focuses on self-creation.

In Truth and Method (2004), Gadamer wrote at length about the importance of asking just the right sort of question in just the right kind of way. He says, for instance, that in order to be able to genuinely ask, one must want to know, and that means knowing that one does not know (p. 157); that "the art of questioning, is the art of questioning ever further-i.e., the art of thinking" (p. 160). 
Saying that "genuine questioning requires that one must want to know," in turn, gives rise to the provocative question of what precisely, in this instance, the teacher, in questioning Johnny why he thought that hitting Frankie in response to Frankie hitting him was a good idea, wants to know. The only answer that seems to fit here is that the teacher wants to know who it is that Johnny is trying to become; that the teacher wants to know Johnny as a person.

If this is true, then again, facilitators of Communities of Inquiry, or again anyone engaged in any interpersonal interchange, needs to become far more engaged than has hitherto been recognized; we need to follow up contributions with the kind of liberating questions that begins to lay bare the unique perspectives of others as the unique individuals they are becoming.

\section{(iii) "Process-" versus "Object"-language.}

"The window broke because it was hit by a stone." "The dog barked because it heard a noise in the backyard." "I hit Frankie because he hit me." What do these three claims have in common? What these statements have in common is the underlying assumption that the event cited in the reason explains the event cited in the conclusion. This language of explanation, in turn, is one that makes sense only on the assumption that there is a stable causal deterministic nexus such that, with foresight, the event cited in the conclusion could have been predicted. The use of the language of explanation, in other words, suggests that the speaker views him/herself more as a product of external forces, than as a person in charge of her own destiny.

This viewpoint contrasts sharply with the language of justification, e.g., "I hit him because I wanted to send the message that I refuse to be a victim of his bullying." This language suggests that the speaker believes that he is required to account for his decisions: that he must answer for, and hence is assumed to have had control over his actions, as opposed to explaining 
that he is this kind of object that has these kinds of definitive properties that are outside of his control.

If one is not lucky enough to be in a highly benevolent environment, then viewing oneself as an object like other objects can do double damage. Not only can it extinguish the exhilaration that comes with a robust sense of self-determination, it can solidify injuries into stable predicates. Thus, for instance, if Johnny views himself as he views other ordinary objects, it follows that he believes that, if he is subjected to harsh destructive external forces, like other objects, he can rightly view himself as damaged goods. What is missing in such a situation-what in fact can be redeemed through the language of freedom, is Johnny's recognition that whether or not Johnny as a person is indeed damaged goods, is entirely within Johnny's hands. What is missing here is that Johnny does not understand that he is being called into account; that regardless of external stimuli, Johnny is nonetheless responsible for the evaluative predicates that stick to him as a result of actions that are within his control. And what is missing here, perhaps, most importantly is the potential mitigating impact that a future vision can have on present predicates.

Thus, for Johnny to motivationally engage in this process of authentic self-creation, he must first become awake to, and thereafter, constantly vigilant to, its possibility. And this is where the language of freedom comes in. What we are proposing here is that the language we use, and/or allow, in dialogue with one another can either enhance a sense of responsibility and hence activate the goal of autonomy and authenticity, or it can solidify a sense of being a victim of circumstance. What needs to happen in interpersonal interchange, whether one-on-one or in community, is that a description of an event that is offered as an explanation ought to be rejected as inappropriate for persons, and there should follow an insistence that, instead, a justification in terms of motives be offered.

\section{3) Becoming "Tinker-Thinkers."}


Like the notions of "freedom" and "authenticity," the conceptual confusions that surround the notions of what counts as "thinking" and/or "reasoning" have disastrous consequences. Many, perhaps most, people assume that they are reasoning if they offer a reason - any old reason-after first promulgating a conclusion that they intuitively believe and/or want to be true. Since they believe that they, and their positions, are "reasonable," they squelch utterly any inclination either to doubt their own position or seriously contemplate the merits of opposing views.

Following Gardner (2014), this can be described as a "pathological" state. She argued strenuously that we must work hard to sell the "reason game," i.e., that we owe it to our children that they learn that what counts as reasoning is not up to them. That reasoning, rather, is something that is governed by objective norms (Darwell, 2006); and that it must transpire in public space so that the worth of all truth-contenders can be estimated by their ability to survive counterexample and alternative comparison. This approach, outlined in detail by Gardner (2009), echoes the theoretical framework offered by Jurgen Habermas in his book The Theory of Communicative Action (1992).

Since then, with colleague Amy Leask, Gardner has worked to create an app and kid's book that invites youngsters to become "Tinker Thinkers" (2014). This initiative aims to teach children: (1) that they can't tell whether or not an act is good or bad until they know the reason behind it: i.e., learn the importance of asking "why?"; (2) that they must see the silent reason that always comes attached with the stated reason; and, thereafter (3) that they can separate good from bad reasons by subjecting them to counterexamples; (4) and, in so doing, become convinced, as a result, that what counts as a good reason is not up to them. This kind of knowledge of specific logical moves, along with "facilitated" exposure to opposing viewpoints- 
as happens in Communities of Inquiry — will equip youngsters with highly effective skills to genuinely reason their way toward truth.

With regard to authenticity, the payoff for being able to reason well is multifaceted. On the one hand, learning how to reason creates a habit of reasoning before acting, speaking and judging, and it is this preamble that, more than anything, will hook into the sense of selfdetermination. Secondly, the security with which evaluative judgments are structured into one's identity will be enhanced as a function of the strength of the reasons that back them. Third, since one comes to appreciate that reasoning is a function of objective rules, if faced with otherwise persuasive pressure from peers, one can appeal to an internal "Kingdom of Ends" for guidance. And finally, since one knows that the strength of any reason is a function of the degree to which it can withstand both counterexample and alternative options, one (hopefully) will be more prone to stay open to opposing views, in the knowledge that such an attitude contributes to stability of one’s very self.

\section{Conclusion}

So the take-home message from all the above is that whether we like it or not, we are all in the business of self-creation that can either succeed or fail as function of the degree to which it approaches authenticity. If authenticity is the goal, then what an authentic self actually looks like needs to become common currency. And since a specific kind of dialogue, one we have referred to as the "language of freedom" seems necessary for authentic self-creation, this is the sort of language that we all ought to adopt whether in personal or pedagogical interaction. And finally, since the stability of self-definition is a function of the reasoning that transpires before judging, speaking and acting, and since evaluative self-predicates are only kept in place by reason's glue, then learning how to reason ought to be considered a human right. 
Taylor (2003) argued that since authenticity is so important, i.e., "it allows us to live (potentially) a fuller and more differentiated life because more fully appropriated as our own” (p.74), and since conceptual confusion can send us in the opposite direction, what we ought to be doing is fighting over the meaning of authenticity. This, along with suggestions as to how to enhance authenticity in our everyday world, as well as in the classroom, has been the goal of the present enterprise.

\footnotetext{
${ }^{1}$ This worry, interestingly, echoes that of Hegel's that he outlines in The Elements of the Philosophy of Right, and discussed in detail by Axel Honneth in his book The Pathologies of Individual Freedom; Hegel's Social Theory. (2010) Princeton: Princeton University Press, p. 45.

${ }^{2}$ As might happen in a classroom exercise in which students are encouraged to imagine what kind of people they "authentically" want to become.
} 


\section{References}

Bloom, A. (1987). The closing of the American mind. New York: Simon \& Schuster.

Darwall, S. (2006). The second-person standpoint: Morality, respect, and accountability. Cambridge, MA: Harvard University Press.

Frankl, V. (1984). Man's search for meaning. New York: Pocket Book.

Gadamer, H.-G. (2004). Truth and method (J. Weinsheimer \& D. G. Marshall, Trans.) (2 $2^{\text {nd }}$ ed). New York: Continuum.

Gardner, S. T. (1995). "Inquiry is no mere conversation: It is hard work.” The Australian Journal for Critical and Creative Thinking, 3(2), 38-49.

Gardner, S. T. (2009). Thinking your way to freedom: A guide to owning your own practical reasoning. Philadelphia: Temple University Press.

Gardner, S. T. \& Leask, A. (2014). Tinker thinkers. Milton, On.: Enable Training and Consulting, Inc.

Gardner, S. T. (2015). “Selling the reason game.” Teaching Ethics, 15(1), 129-136.

Habermas J. (1992). The theory of communicative action,_Vol. 1. (T. McCarthy, Trans.). Boston: Beacon Press.

Klaassen, D. (2014) Existential analysis. Lecture on given at Capilano Univeristy, October 24.

Laing, R. D. (1969) Self and others. Middlesex, England; Penguin Books.

Laing, R.D. (1972) The divided self. London: Pelican Books. 
Mead, G. H. (1965) On social psychology (A. Strauss, Ed). Chicago: Chicago University Press.

Reznitskaya, A. (2012). Dialogic thinking: Rethinking language use during literature discussions. The Reading Teacher, 65(7), 446-456.

Siegel, D. (2012). The developing mind: How relationships and the brain interact to shape who we are ( $2^{\text {nd }}$ ed). New York: The Guilford Press.

Taylor, C. (2003). The ethics of authenticity $\left(11^{\text {th }}\right.$ ed). Cambridge, MA.: Harvard University Press. 